\title{
PENGARUH PENDEKATAN PEMBELAJARAN MATEMATIKA REALISTIK BERBASIS PORTOFOLIO TERHADAP KOMPETENSI PENGETAHUAN MATEMATIKA
}

\author{
Km. Tria Marselina \\ Program Studii Teknologi Pendidikan, Universitas Pendidikan \\ Ganesha mingtria10@yahoo.com \\ MG. Rini Kristiantari \\ Program Studii Teknologi Pendidikan, Universitas Pendidikan \\ Ganesha riniokanegara@gmail.com
}

\begin{abstract}
Abstrak
Tujuan penelitian ini adalah untuk mengetahui perbedaan yang signifikan kompetensi pengetahuan matematika antara kelompok siswa yang dibelajarkan menggunakan pendekatan pembelajaran matematika realistik berbasis portofolio dan kelompok siswa yang dibelajarkan menggunakan pembelajaran konvensional siswa kelas V SD Gugus Moch.Hatta Tahun Ajaran 2017/2018. Jenis penelitian ini merupakan eksperimen semu dengan menggunakan desain penelitian non-equivalen. Populasi penelitian ini adalah seluruh siswa kelas V SD Gugus Moch.Hatta Tahun Ajaran 2017/2018 yang banyaknya 332 orang. Sampel ditentukan dengan random sampling dengan mengacak kelas. Sampel dalam penelitian ini adalah kelas V SD N 4 Panjer sebagai kelompok eksperimen berjumlah 35 orang dan kelas V SD N 1 Panjer sebagai kelompok kontrol dengan berjumlah 30 orang. Data kompetensi pengetahuan matematika dikumpulkan dengan instrumen berupa tes esay berjumlah 8 soal yang telah divalidasi. Data kompetensi pengetahuan matematika dianalisis dengan uji-t. Hasil analisis menunjukkan bahwa terdapat perbedaan yang signifikan kompetensi pengetahuan matematika antara kelompok siswa yang dibelajarkan menggunakan pendekatan pembelajaran matematika realistik berbasis portofolio dan yang dibelajarkan menggunakan pembelajaran konvensional siswa kelas V Sd Gugus Moch.Hatta Tahun Ajaran 2017/2018. Hal tersebut dibuktikan dengan hasil thitung $=7,44>$ ttabel $=2,000$ dengan $\mathrm{dk} 63$ pada taraf signifikansi 5\%. Demikian pula nilai rerata kompetensi pengetahuan matematika siswa kelompok eksperimen $=84,20>=66,77$ rerata kompetensi pengetahuan matematika kelompok kontrol. Dengan demikian dapat disimpulkan bahwa pendekatan pembelajaran matematika realistik berbasis portofolio berpengaruh terhadap kompetensi pengetahuan matematika siswa kelas V SD Gugus Moch.Hatta Tahun Ajaran $2017 / 2018$
\end{abstract}

Kata Kunci: Pendekatan pembelajaran matematika realistik, portofolio, matematika

\begin{abstract}
The purpose of this research is to know the significant difference competence of mathematics knowledge among student group that is taught using realistic mathematics learning approach based on portfolio assessment and group of students which is taught using conventional learning of V class student in Elementary School Cluster Moch.Hatta Lesson 2017/2018 year. The type of this research is a pseudo experiment using a non-equivalent research design. The population of this research is all students of V class in Elementary School Cluster Moch.Hatta Lesson 2017/2018 year which are there is 332 people. The sample is determined by random sampling by randomizing the class. The sample in this research is V class in 4th Elementary School in Panjer as experiment group amount 35 people and V class in Elementery School in Panjer as a control group with 30 people. The competence data of mathematical knowledge were collected with an essay test instrument consisting of 8 validated questions. The competence data of mathematical knowledge were analyzed by t-test. The result of the analysis shows that there is a significant difference of mathematical knowledge competence among student group which is utilized using realistic mathematics learning approach based on portfolio assessment and that is taught using conventional learning of V class student in Elementary School Cluster Moch.Hatta Lesson Year 2017/2018. This is evidenced by the result tcount $=$ $7.44>$ ttable $=2,000$ with $\mathrm{dk} 63$ at 5\% significance level. Similarly, the average score of competence of mathematics knowledge of experimental group students $=84.20>=66.77$ average competence of mathematical knowledge of group control. Thus it can be concluded that the approach of realistic mathematics learning based on portfolio assessment affects the competence of mathematics knowledge of grade V in Elementary School Cluster Moch.Hatta Lesson 2017/2018 year.
\end{abstract}

Keywords: Approach to realistic mathematics learning, portfolio, math. 


\section{Pendahuluan}

Pendidikan merupakan suatu sistem atau subsistem dari sistem yang lebih luas. Kualitas pendidikan merupakan proses sinergis keikutsertaan dan keberfungsian semua komponen pendidi-kan dalam kegiatan pendidikan pada setiap jenjang maupun satuan pendidikan. Menurut Damsar (2011:8) "pendidikan merupakan proses pengubahan sikap dan tingkah laku seseorang atau kelompok orang dalam usaha mendewasakan manu-sia melalui upaya pengajaran atau pelatihan. Salah satu bidang studi yang ada pada semua jenjang pendidikan adalah matematika.

Bidang studi matematika merupa-kan salah satu komponen pendidikan da-sar dalam bidang-bidang pengajaran. Bidang studi matematika ini diperlukan untuk proses perhitungan dan proses berpikir yang sangat dibutuhkan orang dalam menyelesaikan berbagai masalah. Matematika merupakan salah satu disiplin ilmu yang dapat meningkatkan kemam-puan berpikir dan berargumentasi, memberikan konstribusi dalam penyelesa-ian masalah sehari-hari (Susanto, 2013). Dalam belajar matematika, kita akan belajar menalar secara kritis, kreatif dan aktif.

Pendidikan matematika di tanah air saat ini sedang mengalami perubahan paradigma.Terdapat kesadaran yang kuat, terutama di kalangan pengambil kebijak-an, untuk memperbarui pendidikan mate-matika.Tujuannya adalah agar pembela-jaran matematika lebih bermakna bagi siswa dan dapat memberikan bekal kom-petensi yang memadai baik untuk studi lanjut maupun untuk memasuki dunia kerja.

Paradigma baru pendidikan lebih menekankan pada peserta didik sebagai manusia yang memiliki potensi untuk belajar dan berkembang. Siswa harus aktif dalam pencarian dan pengembangan pengetahuan.Kebenaran ilmu tidak terbatas pada apa yang disampaikan oleh guru. Guru harus mengubah perannya, tidak lagi sebagai pemegang otoritas tertinggi keilmuan dan indoktriner, tetapi menjadi fasilitator yang membimbing siswa ke arah pembentukan pengetahuan oleh diri mereka sendiri. Melalui para-digma baru tersebut diharapkan di kelas siswa aktif dalam belajar, aktif berdiskusi, berani menyampaikan gagasan dari orang lain, dan memiliki kepercayaan diri yang tinggi (Hadi, 2017).

Dalam proses pembelajaran mate-matika, baik guru maupun siswa bersama-sama menjadi pelaku terlaksananya tujuan pembelajaran. Tujuan pembelajaran ini akan mencapai hasil yang maksimal apabila pembelajaran berjalan secara efektif. Pembelajaran yang efektif adalah pembelajaran yang mampu melibatkan seluruh siswa secara aktif. Menurut Susanto (2013:53) "pembelajaran efektif merupakan tolak ukur keberhasilan guru dalam mengelola kelas". Dengan demi-kian, diketahui bahwa proses pem-be-lajaran matematika bukan sekedar transfer ilmu dari guru ke siswa, melainkan suatu proses kegiatan, yaitu terjadi interaksi antara guru dengan siswa serta antara siswa dengan siswa, dan antara siswa dengan lingkungannya.

Dalam pembelajarannya, siswa bukan hanya sekedar penerima yang pasif terhadap materi matematika yang siap saji, tetapi siswa perlu diberi kesempatan untuk menemukan matematika melalui praktik yang mereka alami sendiri.Tetapi pada kenyataannya masih banyak siswa yang kurang paham materi kompetensi pengetahuan matematika yang diajarkan. Muatan materi matematika dianggap sebagai pembelajaran yang sulit dan tidak menarik karena bersifat membosankan untuk dipelajari.

Pada kenyataannya masih banyak siswa yang kurang paham materi kom-petensi pengetahuan matematika di kelas.Selain itu masih banyak keluhan dari siswa tentang materi pembelajaran mate-matika. Dilihat dari nilai raport siswa ter-dapat 158 orang yang belum tuntas dalam pembelajaran matematika. Berdasarkan permasalahan tersebut sehingga perlu adanya inovasi baru dalam pembelajaran matematika agar semua siswa men-da-patkan nilai tuntas.

Istilah pendekatan dapat dipahami sebagai suatu jalan, cara atau kebijak-sanaan yang ditempuh oleh guru atau sis-wa dalam pencapaian tujuan pengajaran dilihat dari sudut bagaimana proses pe-ngajaran atau materi pengajaran itu, umum atau khusus dikelola (Susan-to,2013:194)

Jadi, pendekatan pembelajaran dapat diartikan sebagai titik tolak atau sudut pandang kita terhadap proses pem-belajaran, yang merujuk pada pandangan tentang terjadinya suatu proses yang sifatnya masih sangat umum, di dalamnya mewadahi, menginspirasi, menguatkan, dan melatari metode pembelajaran de-ngan cakupan teoritis tertentu.

Pendekatan yang sangat popular saat ini dalam pembelajaran matematika yaitu pendekatan pembelajaran matema-tika realistik (PMR), di luar negeri dikenal dengan sebutan Realistic Mathematics Educations, yang digagas oleh seorang ahli matematika dari Utrect University Netherland, Prof. Hans Freduenthal.

Pendidikan Matematika Realistik tidak dapat dipisahkan dari Institut Freudenthal. Institut ini didirikan pada tahun 1971, nama Institut diambil dari nama pendirinya, yaitu Profesor Hans Freudenthal, seorang penulis, pendidik, dan matematikawan berkebangsaan Jer-man/Belanda. Penerapan Pendidikan Ma-tematika Realistik di Indonesia sudah berlangsung cukup lama, yaitu kurang lebih sepuluh tahun.

Menurut filsafat Pendekatan Mate-matika Realistik siswa harus diberi ke-sempatan untuk merekacipta kembali (to reinvent) matematika di bawah bimbingan orang dewasa, dan rekacipta ide dan angit (konsep) matematika tersebut harus dimulai dari penjelajahan berbagai per-soalan dan situasi 'dunia nyata' (Hadi, 2017:9).

Pendekatan pembelajaran mate-matika realistik merupakan salah satu pendekatan pembelajaran matematika yang berorientasi pada siswa, bahwa matematika adalah aktifitas manusia dan matematika harus 
dihubungkan secara nyata terhadap konteks kehidupan sehari-hari siswa ke pengalaman belajar yang berorientasi pada hal-hal yang real (nyata) (Susanto,2013:205)

Menurut Tarigan dalam Pradipta (2013)"pendekatan pembelajaran mate-matika realistik merupakan pendekatan yang orientasinya menuju kepada pe-nalaran siswa yang bersifat realistik sesuai dengan tuntutan kurikulum berbasis kom-petensi yang ditujukan kepada pengem-bangan pola pikir praktis, logis, kritis dan jujur dengan berorientasi pada penalaran matematika dalam menyelesaikan masa-lah". Kebermaknaan konsep matematika merupakan konsep utama dari pendidikan matematika realistik. Proses belajar siswa hanya akan terjadi jika pengetahuan yang dipelajari bermakna bagi siswa. Suatu pengetahuan akan menjadi bermakna bagi siswa jika proses pembelajaran dilaksa-nakan dalam suatu konteks.

Dalam pendekatan pembelajaran matematika realistik ini ditegaskan bahwa matematika esensinya ialah sebagai aktifitas manusia (human actifity).Dalam pembelajarannya, siswa bukan sekedar penerima yang pasif terhadap materi matematika yang siap saji, tetapi siswa perlu diberi kesempatan untuk reinvent (menemukan) matematika melalui praktik yang mereka alami sendiri.

Suatu prinsip utama pendekatan pembelajaran matematika realistik adalah siswa harus berpartisipasi secara aktif dalam proses belajar. Siswa harus diberi kesempatan untuk membangun pengeta-huan dan pemahaman mereka sendiri. Konsep-konsep matematika yang bersifat abstrak perlu ditransformasika menjadi halhal yang bersifat real bagi siswa (Susanto,2013:205). Begitu juga menurut Wahidin (2014) yang menyatakan "Secara teoritis pendekatan pembelajaran mate-matika realistic dapat memberikan jawa-ban untuk permasalahan motivasi, ke-mampuan pemecahan masalah dan prestasi belajar. Alasan dugaan tersebut adalah karena pendekatan pembelajaran matematika realistik merupakan pende-katan pembelajaran matematika di seko-lah yang dilaksanakan dengan mene-patkan masalah nyata (konstektual), dan lingkungan siswa sebagai titik awal pembelajaran. Siswa diberi kebebasan un-tuk menyelesaikan masalah tersebut de-ngan caranya sendiri baik secara individu maupun dalam kelompok kecil. Kemudian dengan bimbingan guru siswa diarahkan untuk dapat merumuskan penyelesaian masalah tersebut dalam bentuk mate-matika formal".

Karakteristik utama pendekatan pembelajaran matematika realistik menu-rut Aisyah dkk dalam pradipta (2013) adalah sebagai berikut.

(a)Pembelajaran harus dimulai dari masalah kontekstual yang diambil dari dunia nyata. Masalah yang digunakan se-bagai titik awal pembelajaran harus nyata bagi siswa agar mereka dapat langsung terlibat dalam situasi yang sesuai dengan pengalaman mereka. (b) Dunia abstrak dan nyata harus dijembatani oleh model. Model harus sesuai dengan tingkat abs-traksi yang harus dipelajari siswa. Di sini model, dapat berupa keadaan atau situasi nyata dalam kehidupan siswa, seperti cerita-cerita lokal atau bangunan-ba-ngu-nan yang ada di tempat tinggal siswa. (c) Siswa dapat menggunakan strategi, baha-sa, atau simbol mereka sendiri dalam pro-ses mematematikakan dunia mereka. Arti-nya, siswa memiliki kebebasan untuk me-ngekspresikan hasil kerja mereka dalam menyelesaikan masalah nyata yang diberikan oleh guru. (d) Proses pembe-la-jaran harus interaktif. Interaksi baik antara guru dan siswa maupun antara siswa de-ngan siswa merupakan elemen yang penting dalam pembelajaran matematika. Di sini siswa dapat berdiskusi dan bekerja sama dengan siswa lain, bertanya dan menanggapi pertanyaan serta mengeva-luasi pekerjaan mereka. (e) Hubungan diantara bagian-bagian dalam matematika, dengan disiplin ilmu lain, dan dengan masalah dari dunia nyata diperlukan seba-gai satu kesatuan yang saling kait mengait dalam penyelesaian masalah.

Dalam pendekatan pembelajaran matematika realistik, matematika disajikan sebagai suatu proses, sebagai kegiatan manusia, bukan sebagai produk jadi. Unsur menemukan kembali (reinvent) sangat penting. Bahan peljaran disajikan melalui bahan yang sesuai dengan lingkungan siswa. Pendekatan pembe-lajaran matematika realistik menekankan kepada konstruksi dari konteks benda-benda konkret sebagai titik awal bagi siswa guna memperoleh konsep matema-tika (Susanto,2013:206).

Oleh karena itu, dalam pembe-lajaran matematika yang menggunakan pendekatan pembelajaranmatematika rea-listik ini menganut prinsip-prinsip, sebagai berikut : (a) Didominasi oleh masalahma-salah dalam konteks, melayani dua hal yaitu sebagai sumber dan sebagai terapan konsep matematika. (b) Perhatian dibe-rikan kepada pengembangan model-mo-del, situasi, skema, dan simbol-simbol. (c) Subangan dari pada siswa, sehingga dapat membuat pembelajaran menjadi konstruktif dan produktif. (d) Interaktif se-bagai karakteristik dari proses pembe-lajaran matematika. (e) Intertwining (mem-buat jalinan) antartopik atau anatarpokok bahasan atau antarstrand.

Kerangka pembelajaran matema-tika dengan pendekatan pembelajaran matematika realistik menuntun siswa dari keadaan yang sangan konkret menuju yang abstrak. Para siswa dibimbing oleh masalah-masalah kontekstual. Dalam fal-safah realistis, dunia nyata digunakan se-bagai titik pangkal permulaan dalam pengembangan konsep-konsep dan gaga-san mereka (Susanto,2013).

Pembelajaran matematika dengan Pendekatan Pembelajaran Matematika Realistik memiliki aspek-aspek sebagai berikut (Hadi, 2017) : (a) Memulai pembe-lajaran dengan mengajukan masalah (soal) yang "riil" bagi siswa sesuai dengan pengalaman dan tingkat pengetahuannya, sehingga siswa segera terlibat dalam pelajaran secara bermakna. (b) Permasa-lahan yang diberikan tentu harus diarah-kan sesuai dengan tujuan yang ingin dicapai dalam pelajaran tersebut. (c) Sis-wa mengembangkan atau menciptakan model-model simbolik secara 
informal terhadap persoalan/masalah yang dia-jukan. (d) Pengajaran berlangsung secara interktif: siswa menjelaskan dan mem-berikan alasan terhadap jawaban yang diberikannya, memahami jawaban teman-nya (siswa lain), setuju terhadap jawaban temannya, menyatakan ketidak setujuan, mencari alternatif penyelesaian yang lain. (e) Melakukan refleksi terhadap setiap langkah yang ditempuh atau terhadap hasil pelajaran.

Dalam pendekatan pembelajaran matematika realistik siswa tidak dapat dipandang sebagai botol kosong yang harus diisi dengan air. Sebaliknya siswa dipandang sebagai human being yang memiki seperangkat pengetahuan dan pengalaman yang diperoleh melalaui in-teraksi dengan lingkungannya. Selan-jutnya, siswa juga memiliki potensi untuk mengembangkan pengetahuan tersebut bagi dirinya. Di dalam pembelajaran ma-tematika diakui bahwa siswa dapat mengembangkan pengetahuan dan pema-haman matematika apabila diberikan rua-ng dan kesempatan.Siswa dapat mere-konstruksikan kembali temuan-temuan dalam bidang matemaika melalui kegiatan dan eksplorasi berbagai permasalahan, baik permasalahan dalam kehidupan se-hari-hari, maupun permasalahan di dalam matematika sendiri.

Sehingga, secara teoritis pende-katan pembelajaran matematika realistik akan membuat siswa dapat menikmati suasana yang lebih menyenangkan saat pembelajaran, pembelajaran menjadi lebih menarik, menumbuhkan motivasi belajar siswadan membuat pembelajaran menjadi lebih aktif sehingga kompetensi pengeta-huan yang dicapai oleh siswa optimal.

Dengan demikian, dalam Pende-katan Matematika Realistik guru harus mengembangkan pengajaran yang interaktif dan memberikan kesempatan kepada siswa untuk secara aktif ber-partisipasi dalam proses belajar mereka sendiri. Untuk menunjang pelaksanaan pendekatan pembelajaran matematika realistik diperlukan bukti yang dapat menunjukan peningkatan kompetensi pe-ngetahuan matematika siswa. Portofolio merupakan satu ketentuan yang digu-nakan oleh guru untuk mengumpulkan dan mencatat bukti pencapaian peserta didik dalam satu jangka waktu tertentu (Anita Yus, 2006).

Penilaian dalam pendekatan pem-belajaran matematika realistik adalah pe-nilaian didaktis. Artinya, penilaian tersebut berkaitan erat dengan pengajaran dan merupakan bagian praktik pendidikan sehari-hari di kelas. Tujuan penilaian ber-sifat didaktis, artinya berusaha mengum-pulkan data yang meyakinkan tentang siswa dan proses-proses pembelajaran-nya membuat keputusan-keputusan pen-didikan yang khusus.Isi penilaian juga didaktis, maksudnya ini penilaian tidak hanya khusus (terbatas) pada ketram-pilan-ketrampilan yang mudah dinilai, tetapi beberapa tujuan (kompetensi) yang terdapat dalam kurikulum dan secara mendalam. Prosedur penilaian juga ber-sifat didaktis, artinya prosedur yang dite-rapkan merupakan integrasi pengajaran dan penilaian serta merupakan fase dalam proses belajar-mengajar. Alat penilaian juga harus didaktis, artinya alat tersebut harus dapat menggambarkan siswa se-cara lengkap dan utuh, sehingga alat yang digunakan bervariasi sesuai dengan infor-masi yang diperlukan (Hadi,2017:191).

Pendekatan pembelajaran mate-matika realistik berbasis portofolio adalah pendekatan pembelajaran yang orien-tasinya menuju kepada penalaran siswa yang bersifat realistik yang ditujukan pada pola pikir praktis, logis, kritis dan jujur dengan berorientasi pada penalaran ma-tematika dalam penyelesaian masalah. Dalam kegiatan tersebut siswa diberikan tugas-tugas yang berkaitan dengan topic yang dibahas, sehingga melalui tugas-tugas yang diberikan, siswa mempunyai kumpulan karya-karya yang dibuatnya sendiri maupun kelompok yang dijadikan sebagai portofolio siswa. Dengan adanya portofolio ini dapat menunjukkan per-kembangan belajar siswa, sehingga siswa dapat menggambarkan pembelajaran me-reka sendiri.Hal tersebut tentunya dapat dapat menumbuhkan motivasi belajar siswa, dengan demikian hasil belajar yang dicapai oleh siswa menjadi lebih baik.

Berdasarkan paparan diatas maka dilakukan penelitian yang berjudul Pe-ngaruh Pendekatan Pembelajaran Mate-matika Realistik Berbasis Portofolio Ter-hadap Kompetensi Pengetahuan Matema-tika Siswa Kelas V SD Gugus Moch. Hatta Tahun Ajaran 2017/2018, untuk menge-tahui apakah ada perbedaan yang signify-kan hasil belajar matematika siswa yang mengikuti pembelajaran menggunakan Pendekatan Pembelajaran Matematika Realistik Berbasis Portofolio dengan siswa yang mengikuti pembelajaran Konvensional siswa Kelas V SD Gugus Moch. Hatta tahun Ajaran 2017/2018.

\section{Metode}

Jenis penelitian ini adalah penelitian kuantitatif menggunakan rancangan pene-litian eksperimen semu dengan design penelitian Non Equivalent Control Group Design. Pada penelitian ini yang dibandingkan hanya skor postes saja. Postes digunakan untuk menentukan apakah ada perbedaan yang signifikan antara kedua kelompok. Variabel bebas dalam penelitian ini adalah Pendekatan Pembelajaran Matematika Realistik Berbasis Portofolio dan pembelajaran Konven-sional sedangkan variabel terikat yang dalam penelitian ini adalah kompetensi pengetahuan matematika.

Populasi pada penelitian ini adalah seluruh siswa kelas V Sekolah Dasar Gugus Moch.Hatta Tahun Ajaran 2017-/2018, Pengambilan sampel mengguna-kan tekhnik Random Sampling, yang dia-cak adalah kelas. Perandoman dilakukan pada seluruh kelas V di gugus ini yang mana seluruh kelas V di gugus ini dinyatakan setara. Setelah dilakukan pe-randoman, kelas yang didapat adalah Kelas Vb SD Negeri 4 panjer sebagai kelompok eksperimen dan Vb SD Negeri 1 Panjer sebagai kelompok kontrol, untuk meyakinkan 
kesetaraan kedua kelas ini maka dilakukan uji kesetaraan dengan diberikan prates, nilai atau skor dari hasil prates diuji menggunakan uji t yang sebelumnya diuji normalitas dan homo-genitas, uji normalitas dilakukan dengan menggunakan chi kuadrat, berdasarkan perhitungan uji normalitas pada kelas Vb SD Negeri 4 Panjer didapat hitung $=9,49$ kurang dari dari tabel $=11.07$, maka data pada kelas Vb SD Negeri 4 Panjer berdistribusi normal. Perhitungan di kelas Vb SD Negeri 1 Panjer didapat hitung $=-9,10$ kurang dari tabel = 11.07, maka data pada Vb SD Negeri 4 Panjer berdistribusi normal. Setelah dinyatakan kedua data berdistribusi normal, maka dilakukan uji homogenitas, dari perhitungan uji homo-genitas, didapat $=1,74$ kurang dari $=1,84$, maka varians dinyatakan homogen. Data yang telah dinyatakan beristribusi normal dan homogen, Diana-lisis dengan menggunakan uji t, hasil per-hitungan dengan menggunakan uji t didapat bahwa $\mathrm{t}$ hitung $=0,005$ kurang dari $\mathrm{t}$ tabel $=2.000$, maka kedua kelompok dinyatakan setara.

Kelas eksperimen dibelajarkan mengguna-kan Pendekatan Pembelajaran Matema-tika Realistik Berbasis Portofolio. Sedang-kan kelas kelas kontrol dibelajarkan meng-gunakan pembelajaran Konvensional..

Pengumpulan data dilakukan deng-an metode tes. Instrumen yang digunakan adalah tes essay dengan jumlah delapan soal yang sudah dinyatakan valid dan berada pada tingkat reliabilitas yang sa-ngat tinggi.

\section{Hasil dan Pembahasan}

Setelah diberikan perlakuan (treat-ment) menggunakan pendekatan pembe-lajaran matematika realistik berbasis por-tofolio sebanyak 6 kali pada kelompok eksperimen, di akhir eksperimen siswa diberikan pascates untuk memperoleh da-ta kompetensi pengetahuan matematika siswa. Nilai rerata kompetensi penge-tahuan matematika kelas eksperimen yaitu 84,20, berdasarkan PAP maka nilai rerata kompetensi pengetahuan matematika sis-wa pada kelompok eksperimen berada pada predikat Baik.

Setelah diberikan pembelajaran de-ngan pembelajaran konvensional seba-nyak 6 kali pada kelompok kontrol, di akhir eksperimen siswa diberikan pascates un-tuk memperoleh data kompetensi penge-tahuan matematika siswa. Nilai rerata kompetensi pengetahuan matematika ke-las kontrol yaitu 66,77, berdasarkan PAP maka nilai rerata kompetensi pengetahuan matematika siswa pada kelompok kontrol berada pada predikat Cukup.

Uji prasyarat dilakukan terlebih da-hulu sebelum uji hipotesis menggunakan uji t. uji prasyarat tersebut meliputi uji nor-malitas dan uji homogenitas varians diu-raikan sebagai berikut.

Berdasarkan hasil uji normalitas kelompok eksperimen diperoleh chi kua-drat hitung (X2hitung $=6,91$ ) kemudian nilai tersebut dibandingkan dengan chi kuadrat tabel $(\mathrm{X} 2$ tabel $=11,070)$. Hal ini menunjukan bahwa $\mathrm{X} 2$ hitung < X2tabel berarti data hasil penguasaan kompetensi pengetahuan ma-tematika kelompok eksperimen berdis-tribusi normal.

Berdasarkan hasil uji normalitas kelompok kontrol diperoleh chi kuadrat hitung (X2hitung = 6,21)kemudian nilai tersebut dibandingkan dengan chi kuadrat tabel (X2tabel $=11,070)$. Hal ini menunjukan bahwa X2hitung < X2tabel berarti data hasil penguasaan kompetensi pengetahuan matematika kelompok kontrol berdistribusi normal.

Pengujian homogenitas varians an-tar kelompok dumaksud untuk meyakinkan bahwa perbedaan yang diperoleh uji t benar-benar berasal dari perbedaan an-tara kelompok bukan disebabkan oleh perbedaan di dalam kelompok. Uji homo-genitas varians dilakukan dalam penelitian ini menggunakan uji F. Dari hasil analisis diperoleh Fhitung $=1,31$, dan Ftabel $=1,86$. Hal ini berarti Fhitung < Ftabel sehingga data kedua kelompok memoliki varians yang homogen.

Berdasarkan hasil uji prasyarat yang terdiri dari uji normalitas dan uji homo-genitas varians dapat disimpulkan bahwa kedua kelompok sampel ialah berdistribusi noormaldan memiliki varians yang homo-gen. Dengan demikian uji hipotesis meng-gunakan uji t dapat dilakukan.

Hipotesis penelitian yang diuji dalam penelitian ini adalah hipotesis nol (H0) yang berbunyi tidak terdapat perbedaan yang signifikan kompetensi pengetahuan matematika kelompok siswa yang dibe-lajarkan menggunakan pendekatan pem-belajaran matematika realistik berbasis portofolio dengan kelompok siswa yang dibelajarkan menggunakan pembelajaran konvensional pada siswa kelas V SD Gugus Moch.Hatta Tahun Ajaran 2017/ 2018.

Berdasarkan hasil uji normalitas sebaran data dan uji homogenitas varians dapat diketahui bahwa data yang dipe-roleh dari kelompok eksperimen dan kelompok kontrol berdistribusi normal dan memiliki varians yang homogen. Karena data yang diperoleh telah memenuhi uji prasyarat, maka uji hipotesis dapat dila-kukan dengan menggunakan ujit. Berikut disajikan rekapitulasi hasil analisis data dengan menggunakan ujit pada tabel.1 
Tabel 1. Rekapitulasi Uji Hipotesis

\begin{tabular}{cllcccccc}
\hline No & Sampel & $\mathrm{N}$ & $\mathrm{Dk}$ & $\mathrm{X}$ & $\mathrm{S}^{2}$ & $\mathrm{t}_{\text {hitung }}$ & $\mathrm{t}_{\text {tabel }}$ & Status \\
\hline 1 & $\begin{array}{c}\text { Kelompok } \\
\text { eksperimen }\end{array}$ & 34 & & 84,20 & 96,11 & & & \\
2 & $\begin{array}{c}\text { Kelompok } \\
\text { kontrol }\end{array}$ & 29 & 63 & 66,77 & 126,67 & 7,44 & 2,000 & $\mathrm{H}_{0}$ ditolak \\
\hline
\end{tabular}

Dari hasil analisis diperoleh thitung =7,44 dan ttabel $=2,000$ pada taraf signifikansi 5\% dengan dk= 63 . Oleh karena thitung $>$ ttabel maka Ho tang menyatakan tidak terdapat perbedaan yang signifikan kompetensi pengetahuan matematika kelompok siswa yang dibelajarkan menggunakan pendekatan pembelajaran matematika realistik berbasis portofolio dengan kelompok siswa yang dibelajarkan menggunakan pembelajaran konvensional pada siswa kelas V SD Gugus Moch.Hatta ditolak, dan berarti Ha yang menyatakan terdapat perbedaan yang signifikan kompetensi pengetahuan matematika kelompok siswa yang dibelajarkan menggunakan pende-katan pembelajaran matematika realistik berbasis portofolio dengan kelompok sis-wa yang dibelajarkan menggunakan pe-mbelajaran konvensional pada siswa kelas V SD Gugus Moch.Hatta diterima.

Diterapkannya pendekatan pembelajaran matematika realistik berbasis portofolio berpengaruh positif terhadap kompetensi pengetahuan mate-matika siswa. Selama proses pembe-lajaran berlangsung siswa terlihat aktif saat mengikuti pembelajaran, pembe-lajarann menjadi lebih menyenangkan, siswa belajar memecahkan masalah yang diberikan oleh guru, memikirkan berbagai kemungkinan jawaban melalui proses diskusi kelompok yang dimana hasil diskusi tersebut akan dimasukan ke dalam map portofolio. Hal ini dapat dilihat dari hasil perhitungan diketahui bahwa hasil analisis uji t di peroleh thitung > ttabel $(7,44>2,000)$ dengan taraf signifikansi 5\% dan derajat kebebasan 63. Hal tersebut berarti bahwa pembelajaran dengan pendekatan pembelajaran matematika realistik berba-sis portofolio banyak memberikan kesem-patan kepada siswa untuk melakukan aktifitas belajar secara optimal sehingga dapat berpengaruh pada kompetensi pengetahuan matematika.

Pendekatan pembelajaran ma-tematika realistik berbasis portofolio dapat membuat siswa antusias dan termotivasi dalam pembelajaran karena siswa dalam pembelajaran diberi kesempatan meme-cahkan masalah yang sering ditemukan dikehidupan nyata dengan berbasis portofolio yang dapat sebagai tanda bukti hasil kompetensi pengetahuan mate-matika siswa. Menurut Saenz (2009) Pengetahuan kontekstual berkaitan deng-an kemampuan dalam memahami masalah kontekstual yang mencakup kemampuan dalam mengidentifikasi konsep matematika dalam masalalah kon-tekstual, melakukan pemodelan masalah, menyelesaikan masah dengan matematis, sampai mampu menerjemahkan solusi matematis ke dalam solusi real sesuai dengan konteks masalah nyata. Begitu juga menurut Wahidin (2014) yang menyatakan Secara teoritis pendekatan pembelajaran matematika realistik dapat memberikan jawaban untuk permasalahan motivasi, kemampuan pemecahan masalah dan prestasi belajar. Alasan dugaan tersebut adalah karena pendekatan pembelajaran matematika realistik meru-pakan pendekatan pembelajaran mate-matika di sekolah yang dilaksanakan dengan menepatkan masalah nyata (konstektual), dan lingkungan siswa seba-gai titik awal pembelajaran. Siswa diberi kebebasan untuk menyelesaikan masalah tersebut dengan caranya sendiri baik secara individu maupun dalam kelompok kecil.Kemudian dengan bimbingan guru siswa diarahkan untuk dapat merumuskan penyelesaian masalah tersebut dalam bentuk matematika formal. Hal tersebut di dukung oleh Hadi (2013) yang menga-takan pendekatan pembelajaran matema-tika realistik akan membuat siswa dapat menikmati suasana yang lebih menye-nangkan saat pembelajaran, pembelajaran menjadi lebih menarik, menumbuhkan motivasi belajar siswa dan membuat pem-belajaran menjadi lebih aktif sehingga kompetensi pengetahuan yang dicapai oleh siswa optimal.

Berdasarkan paparan tersebut, dapat dikatakan bahwa pendekatan pem-belajaran matematika realistik berbasis portofolio berpengaruh terhadap kompe-tensi pengetahuan matematika siswa kelas V SD Gugus Moch.Hatta tahun ajaran 2017/2018.

\section{Simpulan}

Berdasarkan hasil analisis data kompetensi pengetahuan matematika pada kelompok eksperimen, diketahui bahwa nilai rerata kekompok eksperimen $=84,20$, dengan perolehan nilai mini-mum 62 dan nilai maksimum 100. Ber-dasarkan PAP skala lima maka pada nilai rata-rata kompetensi pengetahuan mate-matika siswa pada kelompok eksperimen berada pada predikat B (Baik)

Hasil analisis data kompetensi pengetahuan matematika pada kelompok kontrol, diketahui bahwa nilai rerata kelompok kontrol $=66,77$ dengan perolehan nilai minimum 50 dan nilai maksimum 90. Berdasarkan PAP skala lima maka pada nilai rata-rata kompetensi pengetahuan matematika siswa pada kelompok kontrol berada pada predikat C (Cukup) 
Hasil analisis uji t diperoleh thitung $=7,44$. Harga tersebut kemudian diban-dingkan dengan harga ttabel dengan dk $35+30-2=63$ pada taraf signifikan 5\% sehingga diperoleh harga ttabel $=2,000$, karena thitung $=7,44>$ ttabel $=2,000$ maka $\mathrm{H} 0$ ditolah dan Ha diterima. Hal ini berarti terdapat perbedaan yang signifikan kom-petensi pengetahuan matematika ke-lompok siswa yang dibelajarkan dengan pendekatan pembelajaran matematika realistik berbasis portofolio dengan kelompok siswa yang dibelajarkan melalui pembelajaran konvensional pada siswa kelas V SD Gugus Moch.Hatta tahun ajaran 2017/2018. Rerata kompetensi pengetahuan matematika siswa kelompok eksperimen $=84,20>=66,77$ rerata kompetensi pengetahuan matematika siswa kelompok kontrol. Sehingga dapat disimpulkan bahwa pendekatan pembe-lajaran matematika realistik berbasis por-tofolio berpengaruh terhadap kompetensi pengetahuan matematika siswa kelas V SD Gugus Moch.Hatta tahun ajaran 2017/2018.

Berdasarkan hasil penelitian ini, maka saran yang dapat diajukan adalah kepada guru, melihat hasil penelitian pada kompetensi pengetahuan matematika de-ngan pendekatan pembelajaran matema-tika realistik berbasis portofolio ini, he-ndaknya guru menerapkan dengan pen-dekatan pembelajaran matematika realis-tik berbasis portofolio pada kompetensi pengetahuan matematika.

Kepada Kepala Sekolah, hen-daknya menyediakan sarana yang mak-simal untuk menunjang pelajaran agar siswa semakin termotivasi untuk belajar dan memanfaat sarana tersebut untuk mengoptimalkan hasil belajar siswa se-hingga mutu sekolah menjadi semakin meningkat

Kepada Peneliti Lain, dengan dilakukannya penelitian ini, diharapkan peneliti lain melakukan penelitian lebih lanjut dengan menerapkan pendekatan pembelajaran matematika realistik berba-sis portofolio pada sumber data/sampel yang berbeda khususnya pada kompe-tensi pengetahuan matematika sehingga hasil penelitian benar-benar dapat meng-gambarkan keadaan sesungguhnya yang terjadi di lapangan.

\section{Daftar Pustaka}

Arikunto, Suharsimi. 2015. Dasar-dasar Evaluasi Pendidikan. Jakarta : PT Bumi Aksara.

Astuti, Ida Ayu, dkk. 2013. "Pengaruh Pendekatan Matematika Realistik Terhadap Prestasi Belajar Matematika Ditinjau Dari Kemampuan Numerik". E-Jurnal Program Pascasarjana Universi-tas Pendidikan Ganesha Juru-san Pendidikan Dasar, Volume 3 tahun 2013.

Badan Standar Nasional Pendidikan (BSNP) 2006 tentang Tujuan Pembelajaran Matematika.

Daryanto. 2014. Pendekatan Pembelaja-ran Saintifik Kurikulum 2013. Yogyakarta : Gava Media.

Hadi, Sutarto. 2017. Pendidikan Matemati-ka Realistik. Jakarta : PT Raja-Grafindo Persada.

Koyan, I Wayan.2012. "Statistika Terapan (Teknik Analisis Data Kuantita-tif)". Singaraja: Universitas Pendidikan Ganesha.

Lestari, Karunia Eka. 2015. "Penelitian Pendidikan Matematika”. Bandung: PT Refika Aditama.

Muhlisin, dkk.2013. "Pengaruh Pendeka-tan Pembelajaran Matematika Realistik Terhadap Hasil Belajar Matematika Ditinjau Dari Tingkat Kecemasan Belajar Siswa”. E-Journal Pascasarjana Unversi-tas pendidikan Ganesha Pro-gram Studi Pendidikan Dasar, Volume 3.

Peraturan Menteri Pendidikan dan Ke-budayaan Republik Indonesia no. 81A.2013 tentang Imple-mentasi Kurikulum.

Peraturan Menteri Pendidikan dan Kebu-dayaan Republik Indonesia no.103.2014 tentang Pem-belajaran Pada Pendidikan Dasar dan Pendidikan Mene-ngah.

Wahidin, Sugiman (2014). "Pengaruh Pendekatan PMRI terhadap Motivasi Berprestasi, Kemam-puan Pemecahan Masalah, dan Prestasi Belajar".Jurnal Pen-didikan Matematika Volume 9 - Nomor 1, Juni 2014, (99-109).

Wijaya, Ariyadi. Pendidikan Matematika Realistik. Yogyakarta : Graha Ilmu.

Wirama,Md, dkk. 2014. "Penaruh Pendekatan Matematika Rea-listik Terhadap Hasil Belajar Matematika Kelas V SD N Desa Penglatan Kecamatan Bulel-eng”. Jurnal Mimbar PGSD Universitas Pendidikan Gane-sha., Volume 2, Nomor 1.

Setyosari, H.Punaji. 2015. Metode Penelitian dan Pengembang-an.Rawamangun : Kencana.

Sugiyono.2017. Metode Penelitian Kuan-titatif, Kualitatif dan R\&D. Bandung : Alfabeta.

Susanto,Ahmad. 2015. Teori Belajar Dan Pembelajaran Di Sekolah Dasar . Jakarta: Kencana.

Yus, Anita 2006. "Penilaian Portofolio untuk Sekolah Dasar". Departe-men Pendidikan nasional.

Yusuf, Muri. 2015. Asesmen dan Evaluasi Pendidikan. Rawamangun: Ken-cana. 